\title{
Segmented Reporting Analysis Pada Anandia Bakery
}

\author{
Resi Rahayu \\ Rangga Putra Ananto \\ Rini Frima
}

Jurusan Akuntansi, Politeknik Negeri Padang

\begin{abstract}
Companies need to know the profit contribution generated by each marketing area owned. To know the profit contribution of each marketing area, it is necessary to create income statement with segmented reporting approach (segmented reporting) each marketing area. Segmented reporting contains information about the amount of sales and certain the costs each marketing area. The purpose of this study is to determine the profit contribution generated by each marketing area in Anandia Bakery April 2017. This study uses variable costing method, which is useful to determine the cost of production just based on variable costs. The results of this study stated that all marketing areas owned by Anandia Bakery in April of 2017 are profitable. It can evidenced by the percentage of segment margin ratio for each large marketing area, it is above 40\%. When the result of margin ratio more larger, the profit contribution that given by the marketing area is getting better.
\end{abstract}

Keywords: Variable Cost, Profit Contribution, and Segmented Reporting Analysis

Abstrak: Perusahaan perlu mengetahui kontribusi laba yang dihasilkan oleh setiap wilayah pemasaran yang dimiliki. Untuk mengetahui kontribusi laba dari masing-masing wilayah pemasaran, maka perlu dibuat laporan laba rugi dengan pendekatan laba rugi segmen (segmented reporting) per wilayah pemasaran. Segmented reporting memuat informasi tentang jumlah penjualan dan biaya-biaya tertentu per wilayah pemasaran. Adapun tujuan dari penelitian ini adalah untuk mengetahui kontribusi laba yang dihasilkan oleh masing-masing wilayah pemasaran pada Anandia Bakery Bulan April Tahun 2017. Penelitian ini menggunakan metode variable costing, yaitu untuk menentukan harga pokok produksi berdasarkan biaya-biaya variabel saja. Hasil dari penelitian ini menyatakan semua wilayah pemasaran yang dimiliki Anandia Bakery pada Bulan April Tahun 2017 menguntungkan. Hal ini dibuktikan dengan persentase rasio margin segmen per wilayah pemasaran yang besar yaitu, diatas $40 \%$. Semakin besar rasio margin yang dihasilkan maka, kontribusi laba yang diberikan wilayah pemasaran tersebut semakin baik.

Kata Kunci: Biaya Variabel, Kontibusi Laba, dan Segmented Reporting Analysis

\section{LATAR BELAKANG}

Pendapatan suatu perusahaan berasal dari pelanggan. Pelanggan merupakan salah satu penunjang eksistensi dari suatu perusahaan. Keberadaan suatu perusahaan ditentukan bukan hanya dari kualitas yang melekat pada produk yang dihasilkan perusahaan, namun ditentukan oleh kemampuan produk dalam pemenuhan kebutuhan pelanggan. Oleh karena itu diperlukan upaya untuk mengelola pelanggan dengan baik dan tepat. Pengelolaan pelanggan dalam hal ini adalah memperlakukan pelanggan sesuai dengan kontribusinya terhadap kelangsungan hidup perusahaan yaitu penciptaan laba. Pelanggan merupakan kunci sukses dalam suatu usaha atau bisnis dalam menghadapi lingkungan bisnis yang kompetitif.

Seiring dengan perkembangan lingkungan bisnis, pelanggan menjadi semakin jeli dan selektif dalam memilih barang dan jasa apa saja yang akan dikonsumsinya. 
Dengan banyaknya tipe dan karakteristik pelanggan, perusahaan harus lebih berhatihati dalam melayani pelanggan dan tetap menjaga hubungan baik antara perusahaan dengan pelanggan. Salah satu cara untuk menjaga hubungan baik dengan pelanggan adalah dengan memberikan pelayanan terbaik. Agar pelaksanaan pelayanan terhadap pelanggan dapat dilakukan dengan akurat dan efektif, sebuah perusahaan dapat mengetahuinya dengan menggunakan laporan laba-rugi segmen. Sebuah segmen adalah subunit dari suatu perusahaan yang cukup penting dalam pembuatan laporan kinerja. Segmen bisa berupa devisi, departemen, lini produk, kelompok pelanggan dan lain-lain (Hansen dan Mowen, 2009 : 573). Dalam pelaporan segmen ini terdapat dua metode perhitungan, yaitu dengan metode variabel costing dan absorpsi costing. Perbedaan antara perhitungan biaya variabel dan biaya absorpsi bergantung pada perlakuan terhadap suatu biaya tertentu, yaitu overhead tetap.

Menurut perhitungan biaya absorpsi, seluruh biaya dibebankan pada unit yang diproduksi. Sedangkan perhitungan menurut biaya variabel, overhead dibagi menjadi overhead variabel dan tetap, dan overhead tetap dibagi menjadi biaya tetap langsung dan biaya tetap umum. Sehingga dapat memberikan informasi tambahan untuk mengetahui mana biaya yang dapat dikendalikan dan mana biaya yang tidak dapat dikendalikan, dan meningkatkan kemampuan manajer untuk mengevaluasi setiap kontribusi segmen terhadap kinerja perusahaan secara keseluruhan (Hansen dan Mowen, 2009 : 573).

GAAP (Generally Accepted Accounting Principles) mensyaratkan perhitungan biaya absorpsi untuk pelaporan eksternal. FASB (Financial Accounting Standards Boards), IRS (Internal Revenue Service), dan lembaga pengatur lainnya tidak menerima perhitungan biaya variabel sebagai metode perhitungan biaya produk untuk pelaporan eksternal. Akan tetapi, perhitungan biaya variabel mampu memberikan informasi biaya yang penting untuk pengambilan keputusan dan pengendalian. Untuk tujuan internal, perhitungan biaya variabel merupakan alat manajerial yang bermanfaat (Hansen dan Mowen, 2009 : 564).

ANANDIA BAKERY merupakan perusahaan manufaktur yang bergerak dalam memproduksi berbagai macam roti. Pada saat ini ANANDIA BAKERY memiliki sebanyak 7 daerah pemasaran aktif baik didalam provinsi maupun diluar Provinsi Sumatera Barat. Daerah pemasaran tersebut antara lain Kerinci, Panyabungan (Sumatera Utara), Padang Panjang, Kayu Aro (Solok), Bangko (Jambi), Pasaman dan Kota Padang. Pada setiap daerah pemasaran ANANDIA BAKERY biasanya akan menitipkan produknya pada \pm 25 toko atau mini market. Selama ini ANANDIA $B A K E R Y$ belum mengetahui bagaimana kontribusi laba yang akan dihasilkan dari setiap pelanggan yang dimilikinya. Kontribusi laba untuk masing-masing pelanggan seharusnya diketahui oleh pemilik, hal ini berguna untuk mengetahui mana saja pelanggan yang memberikan laba yang besar dan mana pelanggan yang memerlukan biaya yang besar. Jika pemilik mengetahui kontribusi laba dari masing-masing pelanggannya, maka pemilik bisa mengambil keputusan terhadap pelanggan. Pemilik bisa lebih meningkatkan penjualan untuk meningkatkan laba, atau pemilik bisa meminimalisir biaya jika pelanggan tersebut memelurkan biaya yang besar.

Berdasarkan dari latar belakang di atas, maka penulis tertarik untuk melakukan penelitian dengan judul "Segmented Reporting Analysis Pada ANANDIA BAKERY". 


\section{METODE PENELITIAN}

Objek penelitian ini adalah usaha Anandia Bakery pada Bulan April Tahun 2017. Setelah dilakukan penelitian, Anandia Bakery memiliki 7 daerah pemasaran yaitu, Daerah Kerinci, Payabungan, Bangko, Padang Panjang, Kayu Aro, Padang, dan Pasaman. Selain itu Anandia Bakery memproduksi 10 jenis roti antara lain, roti tawar panjang, tawar pendek, tawar kupas, tawar pandan, tawar mini, cokelat susu, manis susu, kelapa isi 5, kelapa isi 10 , dan roti satuan.

Pada penelitian ini, pengumpulan data dilakukan dengan teknik wawancara dan observasi. Teknik wawancara yaitu teknik yang dilakukan dengan cara tanya jawab dengan pemilik usaha Anandia Bakeryuntuk memperoleh informasi atau keterangan yang dibutuhkan dalam penelitian. Sedangkan teknik observasi adalah teknik yang dilakukan dengan cara pengamatan terhadap proses operasional yang terjadi pada usaha Anandia Bakery sehingga dapat menguatkan informasi yang kita dapat sebelumnya melalui wawancara.

Dalam penelitian ini, untuk melakukan pelaporan segmen menggunakan pendekatan variabel costing. Pelaporan segmen dengan pendekatan variabel costing dapat memberikan informasi yang akurat tentang profitabilitas setiap daerah pemasaran. Informasi profitabilitas setiap daerah pemasaran dapat digunakan sebagai dasar dalam melakukan perencanaan program atau strategi yang akan dilakukan perusahaan untuk mempengaruhi kebiasaan pelanggan dalam melakukan pembelian, sehingga dapat meningkatkan laba perusahaan secara keseluruhan.

\section{HASIL PENELITIAN Data Penjualan}

Berdasarkan informasi yang penulis peroleh dari pengelola Usaha Anandia Bakery, jumlah produksi roti dalam satu hari tidak tetap, begitupun dengan jenis roti yang diproduksi setiap harinya juga tidak dapat ditentukan. Jumlah dan jenis roti yang akan diproduksi tergantung pada permintaan pasar pada setiap daerah pemasaran yang dimiliki Anandia Bakery itu sendiri. Pada Bulan April Tahun 2017 Usaha Anandia Bakery menerapkan kebijakan untuk libur memproduksi roti setiap Hari Rabu. Selain itu jumlah roti yang diproduksi pada Bulan April Tahun 2017 sebanyak 33.766 bungkus roti. Berikut adalah data penjualan Usaha Anandia Bakery per pelanggan Bulan April Tahun 2017 berdasarkan jenis roti dan untuk penjualan bersih merupakan penjualan (bungkus) dikalikan dengan harga jual masing-masing roti per daerah pemasaran.

Tabel 1

Penjualan setiap Daerah Pemasaran Bulan April Tahun 2017

\begin{tabular}{|c|c|c|c|c|c|c|c|c|c|}
\hline \multirow{3}{*}{ No. } & \multirow{3}{*}{ Jenis Roti } & \multicolumn{7}{|c|}{ Daerah Pemasaran } & \multirow{3}{*}{$\begin{array}{c}\text { Jumlah } \\
\text { Penjualan }\end{array}$} \\
\hline & & Kerinci & Panyabungan & $\begin{array}{l}\text { Padang } \\
\text { Panjang }\end{array}$ & Kayu Aro & Bangko & Padang & Pasaman & \\
\hline & & \multicolumn{7}{|c|}{ Kuantitas (Bungkus) } & \\
\hline 1 & Roti Tawar Panjang & 3.508 & 1.176 & 180 & 834 & 2.186 & 414 & 1.708 & 10.006 \\
\hline 2 & Roti Tawar Pendek & 411 & 124 & 43 & 96 & 256 & 81 & 158 & 1.169 \\
\hline 3 & Roti Tawar Pandan & 415 & 122 & - & 98 & 282 & 61 & 262 & 1.240 \\
\hline 4 & Roti Tawar Kupas & 907 & 328 & 96 & 241 & 721 & 305 & 730 & 3.328 \\
\hline 5 & Roti Tawar Mini & 1.803 & 253 & 29 & 160 & 1.028 & 126 & 380 & 3.779 \\
\hline 6 & Roti Cokelat Susu & 510 & 100 & 59 & 117 & 243 & 333 & 149 & 1.511 \\
\hline 7 & Roti Manis Susu & 516 & 106 & 50 & 143 & 274 & 450 & 165 & 1.704 \\
\hline 8 & Roti Kelapa Isi 5 & 730 & 240 & 12 & 331 & 583 & 959 & 403 & 3.258 \\
\hline 9 & Roti Kelapa Isi 10 & 14 & - & - & 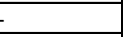 & 199 & 436 & 207 & 856 \\
\hline 10 & Roti Satuan & 83 & - & 33 & 16 & 904 & 73 & 329 & 1.438 \\
\hline \multicolumn{2}{|c|}{ Jumlah } & 8.897 & 2.449 & 502 & 2.036 & 6.676 & 3.238 & 4.491 & 28.289 \\
\hline \multicolumn{2}{|c|}{ Penjualan Bersih (Rp) } & 66.422 .600 & 19.306 .800 & 3.754 .200 & 15.260 .300 & 48.076 .900 & 19.527 .800 & 33.546 .900 & 205.895 .500 \\
\hline
\end{tabular}




\section{Data Aset Tetap}

Tabel 2

Data Aset Tetap "Anandia Bakery"

\begin{tabular}{|c|c|c|c|c|c|c|c|}
\hline No. & Aset Tetap & $\begin{array}{c}\text { Waktu } \\
\text { Perolehan }\end{array}$ & $\begin{array}{c}\text { Umur } \\
\text { Ekonomis }\end{array}$ & Unit & Harga Perolehan & $\begin{array}{l}\text { Total Harga } \\
\text { Perolehan }\end{array}$ & \begin{tabular}{|c|} 
Beban \\
$\begin{array}{c}\text { Penyusutan Per } \\
\text { Bulan }\end{array}$ \\
\end{tabular} \\
\hline 1 & Bangunan Pabrik & $02 / 11 / 2009$ & 10 & 1 & Rp50.000.000 & Rp50.000.000 & Rp416.667 \\
\hline \multirow[t]{3}{*}{2} & Kendaraan: & & & & & & \\
\hline & Mobil & $01 / 12 / 2009$ & 8 & 2 & Rp100.000.000 & Rp200.000.000 & Rp2.083.333 \\
\hline & Mobil & $10 / 12 / 2012$ & 8 & 1 & Rp120.000.000 & Rp120.000.000 & Rp1.250.000 \\
\hline \multirow[t]{14}{*}{3} & Peralatan: & & & & & & \\
\hline & Loyang $30 \times 12 \times 12$ & $05 / 01 / 2012$ & 8 & 160 & Rp40.000 & Rp6.400.000 & Rp66.667 \\
\hline & Loyang 20x11x12 & 05/01/2012 & 8 & 200 & Rp31.000 & Rp6.200.000 & Rp64.583 \\
\hline & Loyang $15 \times 10 \times 10$ & $05 / 01 / 2012$ & 8 & 120 & Rp20.000 & Rp2.400.000 & Rp25.000 \\
\hline & Loyang $30 \times 40 \times 4$ & $05 / 01 / 2012$ & 8 & 150 & Rp22.000 & Rp3.300.000 & Rp34.375 \\
\hline & Timbangan & $05 / 01 / 2012$ & 8 & 1 & Rp400.000 & Rp400.000 & Rp4.167 \\
\hline & Rak Roti & $01 / 03 / 2014$ & 4 & 4 & Rp250.000 & Rp1.000.000 & Rp20.833 \\
\hline & Meja & $01 / 03 / 2012$ & 8 & 4 & Rp375.000 & Rp1.500.000 & Rp15.625 \\
\hline & Keranjang Roti & $01 / 03 / 2014$ & 4 & 60 & Rp50.000 & Rp3.000.000 & Rp62.500 \\
\hline & Kipas Angin & $01 / 03 / 2012$ & 8 & 2 & Rp200.000 & Rp400.000 & Rp4.167 \\
\hline & Kompor Mawar & $05 / 01 / 2012$ & 8 & 2 & Rp200.000 & Rp400.000 & Rp4.167 \\
\hline & Kompor Gas & $05 / 01 / 2012$ & 8 & 1 & Rp200.000 & Rp200.000 & Rp2.083 \\
\hline & Dandang Kukus & $05 / 01 / 2012$ & 8 & 1 & Rp100.000 & Rp100.000 & Rp1.042 \\
\hline & Tabung Gas $12 \mathrm{Kg}$ & $05 / 01 / 2012$ & - & 10 & Rp200.000 & Rp2.000.000 & - \\
\hline \multirow[t]{6}{*}{4} & Mesin: & & & & & & \\
\hline & Mixer Besar & $02 / 11 / 2009$ & 8 & 1 & Rp43.000.000 & Rp43.000.000 & Rp447.917 \\
\hline & Oven & $02 / 11 / 2009$ & 8 & 1 & $\begin{array}{ll}\mathrm{Rp} 80.000 .000 \\
\end{array}$ & Rp80.000.000 & Rp833.333 \\
\hline & Mesin Press & $02 / 11 / 2009$ & 8 & 1 & Rp5.000.000 & Rp5.000.000 & Rp52.083 \\
\hline & Mesin Potong Adonan & $02 / 11 / 2009$ & 8 & 1 & Rp10.000.000 & Rp10.000.000 & Rp104.167 \\
\hline & Mesin Potong Roti & $02 / 11 / 2009$ & 8 & 1 & Rp16.500.000 & Rp16.500.000 & Rp171.875 \\
\hline
\end{tabular}

Usaha Anandia Bakery, sebelumnya tidak ada melakukan perhitungan terhadap penyusutan aset tetap mereka. Namun dalam penelitian ini semua aset tetap yang dimiliki Anandia Bakery akan disusutkan dengan metode garis lurus. Berdasarkan Undang-Undang Nomor 17 Tahun 2000 bangunan semipermanen memiliki umur ekonomis selama 10 tahun. Bangunan pabrik Anandia Bakery merupakan bangunan setengah tiang, karena setengah bagian pabrik terbuat dari kayu dan sebagian lagi terbuat dari bahan yang tahan lama. Sedangkan untuk harta yang bukan bangunan kriteria pengelompokan harta lebih lanjut diatur dalam peratyran menteri keuangan nomor 96/PMK.03/2009 dalam lampiran I-V. Tanah yang digunakan untuk membangun bangunan pabrik tidak termasuk aset tetap Anandia Bakery, karena tanah tersebut disewa dari penduduk sekitar selama 8 tahun dengan harga sewa Rp 48.000.000 mulai dari tanggal 1 Oktober 2009.

\section{Data Biaya}

Dalam menganalisis laporan segmen, hal yang harus dilakukan adalah mengidentifikasi dan mengklasifikasikan semua biaya berdasarkan perilaku biayanya. Biaya dikelompokkan menjadi biaya variabel, biaya tetap, dan biaya semi variabel.

Berdasarkan informasi mengenai biaya-biaya yang dikeluarkan pada Bulan April 2017, yang menjadi biaya semivariabel hanya biaya listrik. Pemisahan biaya semivariabel untuk biaya listrik menggunakan tarif minimum yang telah ditetapkan oleh PT PLN (PERSERO). Usaha Anandia Bakery menggunakan listrik untuk pabriknya dengan daya B2/10600VA. Untuk daya B2/10600 tidak dikenakan biaya abonement, tapi PT PLN menetapkan rekening minimum yaitu (40 jam nyala*10.600/1000)*tarif per kWh. Menurut PT PLN (PERSERO) pada penetapan penyesuaian tarif tenaga listrik ( tarif adjustment) Bulan April-Juni 2017 tarif per kWh untuk daya B2/10600VA sebesar Rp1.467,28. Pada Bulan April Tahun 2017, biaya listrik pabrik Usaha Anandia Bakery sebesar Rp762.000. Maka biaya tetap listrik adalah $40 * 10.600 / 1000 * \operatorname{Rp} 1.467,28=\mathrm{Rp} 622.000$ dan biaya variabel sebesar 
Rp140.000. Tabel berikut akan memperlihatkan klasifikasi biaya berdasarkan perilaku biaya setelah pemisahan biaya semivariabel.

Tabel 3

Biaya Produksi dan Non Produksi pada Bulan April Tahun 2017 (dalam Rupiah)

\begin{tabular}{|c|c|c|}
\hline Keterangan & Biaya Tetap & Biaya Variabel \\
\hline \multicolumn{3}{|l|}{ 1. Biaya Produksi: } \\
\hline Biaya Bahan Baku Langsung & & 85.942 .275 \\
\hline Biaya Tenaga Kerja Tidak Langsung & 20.700 .000 & \\
\hline Biaya Bahan Penolong & & 9.167 .533 \\
\hline Biaya Listrik Pabrik & 622.000 & 140.000 \\
\hline Biaya Pelumas & 20.000 & \\
\hline Biaya Pembungkus & & 1.622 .536 \\
\hline Biaya Lakban & & 47.948 \\
\hline Biaya Isi Ulang Gas & & 5.200 .000 \\
\hline Biaya Perlengkapan Pabrik & 24.000 & \\
\hline Biaya Sewa Tanah & 500.000 & \\
\hline Biaya Penyusutan Bangunan Pabrik & 416.667 & \\
\hline Biaya Penyusutan Pelaratan Pabrik & 305.208 & \\
\hline Biaya Penyusutan Mesin Pabrik & 1.609 .375 & \\
\hline Jumlah Biaya Produksi & 24.197 .250 & 102.120 .291 \\
\hline
\end{tabular}

\begin{tabular}{|l|r|r|}
\hline 2. Biaya Non Produksi & & 202.000 \\
\hline Biaya Telpon Penjualan & & 24.707 .460 \\
\hline Biaya Pengiriman Produk & & 220.000 \\
\hline Biaya Pencairan Giro & 20.000 & \\
\hline Biaya Perlengkapan & 2.700 .000 & \\
\hline Biaya Gaji Sopir dan Tenaga Angkut & 3.333 .333 & \\
\hline Biaya Penyusutan Kendaraan & 950.000 & \\
\hline Biaya Pemeliharaan Kendaraan & $\mathbf{7 . 0 0 3 . 3 3 3}$ & $\mathbf{2 5 . 1 2 9 . 4 6 0}$ \\
\hline Jumlah Biaya Non Produksi & $\mathbf{3 1 . 2 0 0 . 5 8 3}$ & $\mathbf{1 2 7 . 2 4 9 . 7 5 1}$ \\
\hline Total Biaya & \multicolumn{2}{|l}{} \\
\hline
\end{tabular}

\section{PEMBAHASAN}

Mengidentifikasi dan Mengklasifikasi Biaya Berdasarkan Fungsi Pokok Perusahaan

Biaya Bahan Baku

Biaya bahan baku merupakan komponen utama dari suatu produk. Untuk mengetahui biaya bahan baku suatu produk, maka perusahaan harus mengetahui berapa banyak bahan baku yang digunakan oleh perusahaan dan berapa harga belinya. Berikut adalah bahan baku yang dibutuhkan Usaha Anandia Bakery:

1. Jenis bahan baku dan standar biaya bahan baku untuk memproduksi berbagai jenis roti tawar

Untuk memproduksi roti tawar akan membutuhkan tepung terigu sebanyak $25 \mathrm{~kg}$, fres coplus (inti telur) $0,7 \mathrm{~kg}$, gula $2 \mathrm{~kg}$, dan mentega $2 \mathrm{~kg}$. Yang membedakan antara satu jenis roti tawar dengan roti tawar lainnya adalah jumlah roti per bungkus yang akan dihasilkan. Untuk roti tawar panjang akan menghasilkan 80 bungkus roti, 100 bungkus untuk roti tawar pendek, 100 bungkus untuk roti tawar pandan, 100 bungkus untuk roti tawar kupas, dan 120 bungkus untuk roti tawar mini. Untuk menentukan kebutuhan bahan baku per bungkus adalah membagi kuantitas bahan 
baku dengan jumlah roti yang dihasilkan. Contohnya kebutuhan bahan baku untuk satu bungkus roti tawar panjang.

a. Tepung terigu

Untuk menghasilkan 80 bungkus roti tawar panjang membutuhkan $25 \mathrm{~kg}$ tepung terigu. Maka kebutuhan untuk satu bungkus adalah 25:80=0,313kg.

b. Fres Coplus(Inti Telur)

Untuk menghasilkan 80 bungkus roti tawar panjang membutuhkan $0,75 \mathrm{~kg}$ fres coplus. Maka kebutuhan untuk satu bungkus adalah 0,75:80=0,009kg.

c. Gula

Untuk menghasilkan 80 bungkus roti tawar panjang membutuhkan $2 \mathrm{~kg}$ gula. Maka kebutuhan untuk satu bungkus adalah 2:80=0,025kg.

d. Mentega

Untuk menghasilkan 80 bungkus roti tawar panjang membutuhkan $2 \mathrm{~kg}$ mentega. Maka kebutuhan untuk satu bungkus adalah 2:80=0,025kg.

2. Jenis bahan baku dan standar biaya bahan baku untuk memproduksi roti cokelat susu, roti manis susu, roti kelapa, dan roti satuan

Untuk memproduksi roti cokelat susu, roti manis susu, roti kelapa, dan roti satuan akan membutuhkan tepung terigu sebanyak $25 \mathrm{~kg}$, fres coplus (inti telur) $0,7 \mathrm{~kg}$, gula $4 \mathrm{~kg}$, dan mentega $2 \mathrm{~kg}$. Dengan bahan baku tersebut akan menghasilkan roti cokelat susu sebanyak 180 bungkus, 180 bungkus roti manis susu, 280 bungkus roti kelapa isi 5, 140 bungkus roti kelapa isi 10, dan 140 bungkus roti satuan.

Data mengenai kebutuhan bahan baku per bungkus roti dapat dilihat pada tabel berikut:

Tabel 4

\begin{tabular}{|c|c|c|c|c|c|c|c|c|c|c|c|}
\hline \multicolumn{12}{|c|}{ Kebutuhan Bahan Baku Roti Per Bungkus } \\
\hline Bahan Baku & Satuan & $\begin{array}{c}\text { Roti } \\
\text { Tawar } \\
\text { Panjang }\end{array}$ & $\begin{array}{c}\text { Roti } \\
\text { Tawar } \\
\text { Pendek }\end{array}$ & \begin{tabular}{c|} 
Roti \\
tawar \\
Pandan
\end{tabular} & $\begin{array}{c}\text { Roti } \\
\text { Tawar } \\
\text { Kupas }\end{array}$ & $\begin{array}{c}\text { Roti } \\
\text { Tawar } \\
\text { Mini }\end{array}$ & \begin{tabular}{|c|} 
Roti \\
Cokelat \\
Susu \\
\end{tabular} & $\begin{array}{c}\text { Roti } \\
\text { Manis } \\
\text { Susu } \\
\end{array}$ & $\begin{array}{c}\text { Roti } \\
\text { Kelapa } \\
\text { Isi5 } \\
\end{array}$ & \begin{tabular}{|c|} 
Roti \\
Kelapa \\
Isi10
\end{tabular} & $\begin{array}{c}\text { Roti } \\
\text { Satuan }\end{array}$ \\
\hline Tepung Terigu & $\mathrm{Kg}$ & 0,313 & 0,250 & 0,250 & 0,250 & 0,208 & 0,139 & 0,139 & 0,089 & 0,179 & 0,179 \\
\hline Fres Coplus & $\mathrm{Kg}$ & 0,009 & 0,008 & 0,008 & 0,008 & 0,006 & 0,004 & 0,004 & 0,003 & 0,005 & 0,005 \\
\hline Gula & $\mathrm{Kg}$ & 0,025 & 0,020 & 0,020 & 0,020 & 0,017 & 0,022 & 0,022 & 0,014 & 0,029 & 0,029 \\
\hline Mentega & $\mathrm{Kg}$ & 0,025 & 0,020 & 0,020 & 0,020 & 0,017 & 0,011 & 0,011 & 0,007 & 0,014 & 0,014 \\
\hline
\end{tabular}

Berdasarkan informasi yang penulis peroleh dari pengelola Usaha Anandia Bakery 1kg tepung terigu dibeli seharga Rp6.640, 1 kg fres coplus seharga Rp67.500, $1 \mathrm{~kg}$ gula seharga Rp12.600, dan 1 kg mentega seharga Rp17.300. Dari kebutuhan bahan baku pada tabel 4.4 diatas, maka biaya bahan baku yang dikeluarkan per bungkus roti dapat diketahui dengan mengalikan harga bahan baku dengan kebutuhan bahan baku roti per bungkusnya. Berikut merupakan biaya bahan baku yang dikeluarkan masing-masing roti per bungkus. 
Tabel 5

\begin{tabular}{|c|c|c|c|c|c|}
\hline \multicolumn{6}{|c|}{ Biaya Bahan Baku Roti Per Bungkus } \\
\hline Jenis Roti & $\begin{array}{l}\text { Tepung } \\
\text { Terigu }\end{array}$ & $\begin{array}{c}\text { Fres } \\
\text { Coplus }\end{array}$ & Gula & Mentega & Total \\
\hline Roti Tawar Panjang & Rp2.075 & Rp 633 & $\mathrm{Rp} 315$ & $\mathrm{Rp} 433$ & Rp3.455 \\
\hline Roti Tawar Pendek & $\mathrm{Rp} 1.660$ & Rp 506 & $\mathrm{Rp} 252$ & $\mathrm{Rp} 346$ & $\operatorname{Rp} 2.764$ \\
\hline Roti Tawar Pandan & $\operatorname{Rp} 1.660$ & Rp 506 & $\operatorname{Rp} 252$ & Rp 346 & $\operatorname{Rp} 2.764$ \\
\hline Roti Tawar Kupas & $\mathrm{Rp} 1.660$ & Rp 506 & $\mathrm{Rp} 252$ & $\mathrm{Rp} 346$ & $\operatorname{Rp} 2.764$ \\
\hline Roti Tawar Mini & $\operatorname{Rp} 1.383$ & $\mathrm{Rp} 422$ & Rp 210 & $\mathrm{Rp} 288$ & $\operatorname{Rp} 2.304$ \\
\hline Roti Cokelat Susu & Rp 922 & $\mathrm{Rp} 281$ & Rp 280 & Rp 192 & $\operatorname{Rp} 1.676$ \\
\hline Roti Manis Susu & $\mathrm{Rp} \quad 922$ & Rp 281 & Rp 280 & $\mathrm{Rp} 192$ & $\operatorname{Rp} 1.676$ \\
\hline Roti Kelapa Isi 5 & $\mathrm{Rp} \quad 593$ & Rp 181 & $\mathrm{Rp} 180$ & $\mathrm{Rp} 124$ & $\operatorname{Rp} 1.077$ \\
\hline Roti Kelapa Isi 10 & $\mathrm{Rp} 1.186$ & Rp 362 & Rp 360 & Rp 247 & $\mathrm{Rp} 2.154$ \\
\hline Roti Satuan & $\operatorname{Rp} 1.186$ & Rp 362 & Rp 360 & Rp 247 & $\operatorname{Rp} 2.154$ \\
\hline
\end{tabular}

\section{Biaya Tenaga Kerja}

Menurut (Riwayadi, 2016 : 66) biaya tenaga kerja ada dua yaitu biaya tenaga kerja langsung dan biaya tenaga kerja tidak langsung. Biaya tenaga kerja langsung adalah tenaga kerja yang terlibat langsung dalam pembuatan barang jadi dan pembayaran upahnya berdasarkan unit yang dihasilkan atau berdasarkan jam kerja. Biaya tenaga kerja tidak langsung adalah tenaga kerja yang tidak dapat diidentifikasikan langsung dengan barang yang dihasilkan dengan tugas atau pekerjaannya.

Usaha Anandia Bakery, dalam memproduksi roti akan melalui dua departemen yaitu, bagian produksi dan bagian pengemasan. Pada bagian produksi Usaha Anandia Bakery memiliki 9 orang karyawan yang akan bekerja selama 8 jam perharinya, mulai dari jam 08:00 WIB sampai 17:00 WIB dengan istirahat makan selama 1 jam. Sedangkan pada bagian pengemasan Usaha Anandia Bakery mempekerjakan 3 orang karyawan yang bekerja selama 6 jam dalam satu hari, dengan jam kerja mulai dari 10:00 WIB sampai 17:00 WIB dengan istirahat makan selama 1 jam. Usaha Anandia Bakery beroperasi hanya pada hari minggu sampai hari jumat atau sama dengan 26 hari dalam satu bulan. Jumlah gaji yang akan diterima setiap bulannya tetap, sesuai dengan tarif gaji di departemen tempat karyawan bekerja, maka gaji karyawan bagian produksi dan pengemasan merukapan biaya tenaga kerja tidak langsung.

Untuk memasarkan produknya Usaha Anandia Bakery memiliki 3 unit mobil. Pada bagian pemasaran Usaha Anandia Bakery memiliki 5 orang karyawan, 2 diantaranya bertugas sebagai supir, 2 orang bertugas sebagai sales, dan 1 orang bertugas sebagai sopir merangkap sebagai sales.

\section{Biaya Overhead Pabrik}

Biaya overhead pabrik adalah semua biaya produksi selain biaya bahan baku langsung dan biaya tenaga kerja langsung (Riwayadi, 2016 : 69). Pengalokasian biaya overhead pabrik untuk Bulan April Tahun 2017 menggunakan unit produksi, karena jumlah unit dan jenis produk yang diproduksi Usaha Anandia Bakery setiap harinya tidak dapat dipastikan. Berikut adalah biaya overhead pabrik yang terdapat pada Usaha Anandia Bakery. 


\section{Biaya Bahan Penolong}

Bahan penolong merupakan komponen pendukung dari suatu produk. Untuk mengetahui biaya bahan penolong suatu produk, maka perusahaan harus mengetahui berapa banyak bahan penolong yang digunakan oleh perusahaan dan berapa harga belinya. Berikut adalah bahan penolong yang dibutuhkan Usaha Anandia Bakery.

a. Roti Tawar Panjang

- Kalsium, Pengembang, dan Pengempuk Untuk menghasilkan 80 bungkus roti tawar panjang membutuhkan kalsium, pengembang, dan pengembuk masing-masing sebanyak $0,075 \mathrm{~kg}$. Maka kebutuhan untuk satu bungkus adalah masing-masing $0,075: 80=0,0009 \mathrm{~kg}$.

Untuk kalsium dibeli seharga Rp40.000/kg, pengembang dibeli dengan harga Rp34.550/kg, pengempuk dibeli dengan harga Rp59.000/kg.

- Garam

Untuk menghasilkan 80 bungkus roti tawar panjang membutuhkan $0,1 \mathrm{~kg}$ garam. Maka kebutuhan untuk satu bungkus adalah 0,1:80=0,0013kg. Harga beli 1kg garam sebesar Rp8.000.

- Air

Tepung terigu sebanyak 25kg akan membutuhkan air sebanyak 2 liter. Usaha Anandia Bakery menggunakan air yang berasal dari sumur, sehingga biya air akan dibebankan ke biaya listrik. Ketentuan air ini berlaku untuk semua jenis roti.

b. Roti Tawar Pendek

- Kalsium, Pengembang, dan Pengembuk Untuk menghasilkan 100 bungkus roti tawar pendek membutuhkan kalsium, pengembang, dan pengembuk masing-masing sebanyak $0,075 \mathrm{~kg}$. Maka kebutuhan untuk satu bungkus adalah masing-masing $0,075: 100=0,0008 \mathrm{~kg}$.

- Garam

Untuk menghasilkan 100 bungkus roti tawar pendek membutuhkan 0,1kg garam. Maka kebutuhan untuk satu bungkus adalah 0,1:100=0,0010kg.

c. Roti Tawar Pandan dan Roti Tawar Kupas

- Kalsium, Pengembang, dan Pengembuk

Untuk menghasilkan masing-masing 100 bungkus roti tawar pandan dan roti tawar kupas membutuhkan kalsium, pengembang, dan pengembuk masing-masing sebanyak 0,075kg. Maka kebutuhan untuk satu bungkus adalah masing-masing 0,075:100 $=0,0008 \mathrm{~kg}$.

- Garam

Untuk menghasilkan 100 bungkus membutuhkan 0,1kg garam. Maka kebutuhan untuk satu bungkus adalah $0,1: 100=0,0010 \mathrm{~kg}$.

- Perisa Pandan

Untuk menghasilkan 100 bungkus roti tawar pandan dan roti tawar kupas membutuhkan $0,25 \mathrm{~kg}$ perisa pandan. Maka kebutuhan untuk satu bungkus adalah 0,25:100=0,003kg. Perisa pandan dibeli dengan harga Rp128.200/kg.

d. Roti Tawar Mini

- Kalsium, Pengembang, dan Pengembuk Untuk menghasilkan 120 bungkus roti tawar mini membutuhkan kalsium, pengembang, dan pengembuk masing-masing sebanyak 0,075kg. Maka 
kebutuhan untuk satu bungkus adalah masing-masing 0,075:120=0,0006kg.

- Garam

Untuk menghasilkan 120 bungkus roti tawar mini membutuhkan $0,1 \mathrm{~kg}$ garam. Maka kebutuhan untuk satu bungkus adalah 0,1:120=0,0008kg.

e. Roti Cokelat Susu

- Kalsium, Pengembang, dan Pengembuk Untuk menghasilkan 180 bungkus roti cokelat susu membutuhkan kalsium, pengembang, dan pengembuk masing-masing sebanyak 0,075kg. Maka kebutuhan untuk satu bungkus adalah masing-masing $0,075: 180=0,0004 \mathrm{~kg}$.

- Garam

Untuk menghasilkan 180 bungkus roti cokelat susu membutuhkan $0,1 \mathrm{~kg}$ garam. Maka kebutuhan untuk satu bungkus adalah 0,1:180=0,0006kg.

- Cokelat Pasta

Untuk menghasilkan 180 bungkus roti cokelat susu membutuhkan 5kg cokelat pasta. Maka kebutuhan untuk satu bungkus adalah $5: 180=0,0278 \mathrm{~kg}$. Cokelat pasta ini dibeli dengan harga Rp14.500/kg.

- Susu Bubuk

Untuk menghasilkan 180 bungkus roti cokelat susu membutuhkan $0,75 \mathrm{~kg}$ susu bubuk. Maka kebutuhan untuk satu bungkus adalah 0,75:180=0,0042kg. Harga beli untuk $1 \mathrm{~kg}$ susu bubuk adalah Rp51.200.

f. Roti Manis Susu

- Kalsium, Pengembang, dan Pengembuk Untuk menghasilkan 180 bungkus roti manis susu membutuhkan kalsium, pengembang, dan pengembuk masing-masing sebanyak 0,075kg. Maka kebutuhan untuk satu bungkus adalah masing-masing $0,075: 180=0,0004 \mathrm{~kg}$.

- Garam

Untuk menghasilkan 180 bungkus roti manis susu membutuhkan $0,1 \mathrm{~kg}$ garam. Maka kebutuhan untuk satu bungkus adalah 0,1:180=0,0006kg.

- Susu Bubuk Untuk menghasilkan 180 bungkus roti manis susu membutuhkan $0,75 \mathrm{~kg}$ susu bubuk. Maka kebutuhan untuk satu bungkus adalah $0,75: 180=0,0042 \mathrm{~kg}$.

g. Roti Kelapa Isi 5

- Kalsium, Pengembang, dan Pengembuk Untuk menghasilkan 280 bungkus roti kelapa isi 5 membutuhkan kalsium, pengembang, dan pengembuk masing-masing sebanyak 0,075kg. Maka kebutuhan untuk satu bungkus adalah masing-masing $0,075: 280=0,0003 \mathrm{~kg}$.

- Garam

Untuk menghasilkan 280 bungkus roti kelapa isi 5 membutuhkan $0,1 \mathrm{~kg}$ garam. Maka kebutuhan untuk satu bungkus adalah 0,1:280=0,0004kg.

- Isian Kelapa

Untuk menghasilkan 280 bungkus roti kelapa isi 5 membutuhkan $10 \mathrm{~kg}$ isian kelapa. Isian kelapa ini merupakan campuran kelapa parut ditambah dengan gula dan susu bubuk lalu dikukus selama 2 jam. $10 \mathrm{~kg}$ kepala parut akan dicampur dengan $3 \mathrm{~kg}$ gula dan $0,25 \mathrm{~kg}$ susu bubuk. Harga beli $1 \mathrm{~kg}$ 
kelapa parut adalah Rp6.000, $1 \mathrm{~kg}$ gula seharga Rp12.600, dan $1 \mathrm{~kg}$ susu bubuk seharga Rp51.200. jadi total biaya untuk isian kelapa adalah Rp11.060/kg. Kebutuhan isian kelapa untuk satu bungkus adalah $10: 280=0,0357 \mathrm{~kg}$.

h. Roti Kelapa Isi 10

- Kalsium, Pengembang, dan Pengembuk

Untuk menghasilkan 140 bungkus roti kelapa isi 10 membutuhkan kalsium, pengembang, dan pengembuk masing-masing sebanyak 0,075kg. Maka kebutuhan untuk satu bungkus adalah masing-masing $0,075: 140=0,0005 \mathrm{~kg}$.

- Garam

Untuk menghasilkan 140 bungkus roti kelapa isi 10 membutuhkan 0,1 kg garam. Maka kebutuhan untuk satu bungkus adalah 0,1:140=0,0007kg.

- Isian Kelapa Untuk menghasilkan 140 bungkus roti kelapa isi 10 membutuhkan 10kg isian kelapa. Maka kebutuhan untuk satu bungkus adalah $10: 140=0,0714 \mathrm{~kg}$.

i. Roti Satuan

- Kalsium, Pengembang, dan Pengembuk

Untuk menghasilkan 140 bungkus roti satuan membutuhkan kalsium, pengembang, dan pengembuk masing-masing sebanyak 0,075kg. Maka kebutuhan untuk satu bungkus adalah masing-masing $0,075: 140=0,0005 \mathrm{~kg}$.

- Garam

Untuk menghasilkan 140 bungkus roti satuan membutuhkan 0,1kg garam. Maka kebutuhan untuk satu bungkus adalah 0,1:140=0,0007kg.

Data mengenai kebutuhan bahan penolong per bungkus roti dapat dilihat pada tabel berikut:

Tabel 6

Kebutuhan Bahan Penolong Roti Per Bungkus

\begin{tabular}{|c|c|c|c|c|c|c|c|c|c|c|c|}
\hline Bahan Baku & Satuan & \begin{tabular}{|c|} 
Roti \\
Tawar \\
Panjang \\
\end{tabular} & $\begin{array}{c}\text { Roti } \\
\text { Tawar } \\
\text { Pendek }\end{array}$ & \begin{tabular}{|c|} 
Roti \\
tawar \\
Pandan
\end{tabular} & $\begin{array}{c}\text { Roti } \\
\text { Tawar } \\
\text { Kupas } \\
\end{array}$ & \begin{tabular}{|c|} 
Roti \\
Tawar \\
Mini \\
\end{tabular} & \begin{tabular}{|c|} 
Roti \\
Cokelat \\
Susu \\
\end{tabular} & $\begin{array}{c}\text { Roti } \\
\text { Manis } \\
\text { Susu } \\
\end{array}$ & \begin{tabular}{|c|} 
Roti \\
Kelapa \\
Isi 5 \\
\end{tabular} & $\begin{array}{c}\text { Roti } \\
\text { Kelapa } \\
\text { Isi 10 }\end{array}$ & $\begin{array}{c}\text { Roti } \\
\text { Satuan }\end{array}$ \\
\hline Kalsium & $\mathrm{Kg}$ & 0,0009 & 0,0008 & 0,0008 & 0,0008 & 0,0006 & 0,0004 & 0,0004 & 0,0003 & 0,0005 & 0,0005 \\
\hline Garam & $\mathrm{Kg}$ & 0,0013 & 0,0010 & 0,0010 & 0,0010 & 0,0008 & 0,0006 & 0,0006 & 0,0004 & 0,0007 & 0,0007 \\
\hline Pengembang & $\mathrm{Kg}$ & 0,0009 & 0,0008 & 0,0008 & 0,0008 & 0,0006 & 0,0004 & 0,0004 & 0,0003 & 0,0005 & 0,0005 \\
\hline Pengempuk & $\mathrm{Kg}$ & 0,0009 & 0,0008 & 0,0008 & 0,0008 & 0,0006 & 0,0004 & 0,0004 & 0,0003 & 0,0005 & 0,0005 \\
\hline Air & $\mathrm{Kg}$ & 0,0250 & 0,0200 & 0,0200 & 0,0200 & 0,0167 & 0,0111 & 0,0111 & 0,0071 & 0,0143 & 0,0143 \\
\hline Susu Bubuk & $\mathrm{Kg}$ & $t$ & - & 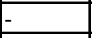 & E & 5 & 0,0042 & 0,0042 & & - & - \\
\hline Cokelat Pasta & $\mathrm{Kg}$ & - & - & - & - & - & 0,0278 & - & - & - & - \\
\hline Isian Kelapa & $\mathrm{Kg}$ & - & - & + & - & - & 5 & - & 0,0357 & 0,0714 & - \\
\hline Perisa Pandan & $\mathrm{Kg}$ & - & - & 0,0025 & 0,0025 & - & & - & & & - \\
\hline
\end{tabular}

Berdasarkan kebutuhan bahan penolong diatas, maka biaya bahan penolong yang dikeluarkan per bungkusnya dapat diketahui dengan mengalikan harga bahan penolong dengan kebutuhan bahan penolong roti per bungkusnya. Tabel berikut merupakan biaya bahan penolong yang dikeluarkan masing-masing roti per bungkus. 
Tabel 7

Biaya Bahan Penolong Roti Per Bungkus

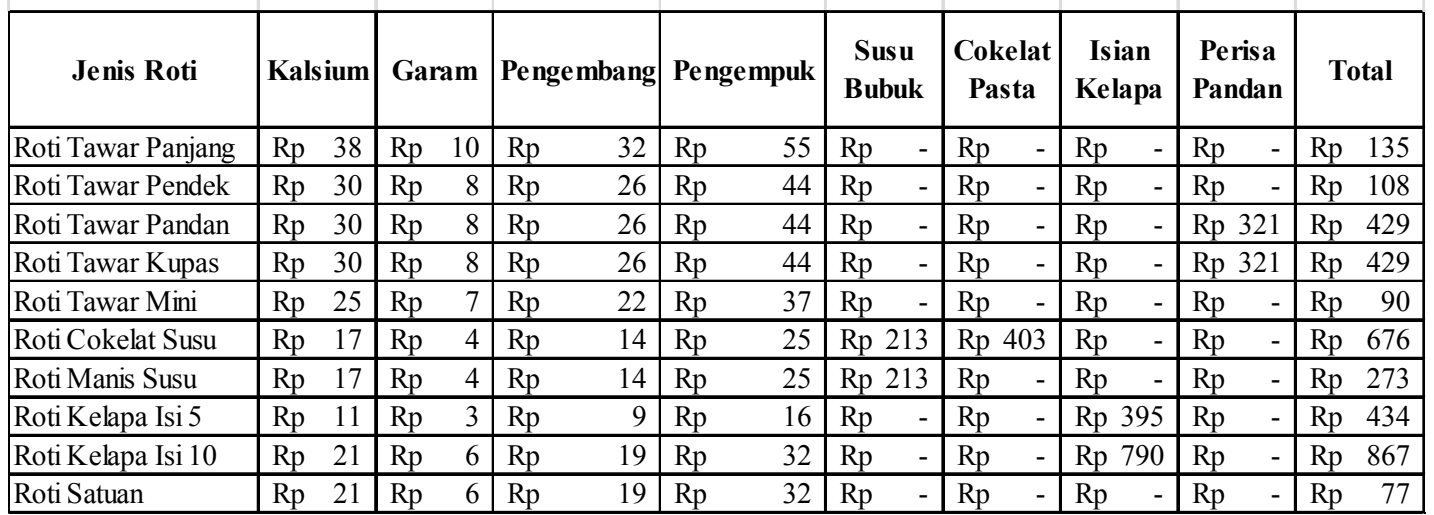

2. Biaya Listrik Pabrik

Biaya listrik merupakan biaya semivariabel. Biaya semivariabel adalah biaya yang memiliki komponen tetap dan variabel. Komponen tetap dalam biaya semi variabel adalah biaya minimum yang dibutuhkan untuk menyediakan jasa, sedangkan komponen variabel adalah jumlah biaya yang dipengaruhi oleh perubahan output aktivitas. Biaya ini akan selalu berubah secara total namun tidak proporsional terhadap output aktivitas (Carter dan Usry 2009:57).

Usaha Anandia Bakery menggunakan listrik untuk pabriknya dengan daya B2/10600VA. Untuk daya B2/10600 tidak dikenakan biaya abonement, tapi PT PLN menetapkan rekening minimum yaitu (40 jam nyala*10.600/1000)*tarif per $\mathrm{kWh}$. Menurut PT PLN (PERSERO) pada penetapan penyesuaian tarif tenaga listrik ( tarif adjustment) Bulan April-Juni 2017 tarif per kWh untuk daya B2/10600VA sebesar Rp1.467,28. Pada Bulan April Tahun 2017, biaya listrik pabrik Usaha Anandia Bakery sebesar Rp762.000. Maka biaya tetap listrik adalah 40*10.600/1000* Rp1.467,28=Rp622.000 dan biaya variabel sebesar Rp140.000. Sehingga biaya overhead pabrik-biaya listrik untuk semua jenis roti sama yaitu jumlah biaya listrik variabel dibagi dengan total produksi selama Bulan April (Rp140.000:33.766=Rp4,15).

\section{Biaya Pembungkus}

Jenis plastik yang digunakan untuk pembungkus semua jenis roti sama, kecuali untuk roti isian kelapa. 25kg plastik polos dibeli dengan harga Rp725.000 dan upah sablon Rp425.000. Dalam 1kg plastik kaca terdiri dari 1000 lembar plastik, sedangkan untuk tebal (untuk roti isian kelapa) dalam $1 \mathrm{~kg}$ plastik terdiri dari 750 lembar. Berikut adalah perhitungan alokasi biaya pembungkus:

$$
\begin{array}{ll}
\text { - } & \text { Plastik Kaca } \\
& =\mathrm{Rp} 46.000 / 1000 \\
& =\mathrm{Rp} 46 \\
\text { - } & \text { Plastik Tebal } \\
& =\mathrm{Rp} 46.000 / 750 \\
& =\mathrm{Rp} 61
\end{array}
$$

\section{Biaya lakban}

Lakban berguna sebagai alat untuk merekatkan pembungkus roti serta untuk membentuk sudut-sudut pembungkus agar lebih rapi. Dalam satu gulung lakban berguna untuk 3.500 bungkus roti. Bulan April Tahun 2017 Anandia Bakery memerlukan 10 gulung lakban, dengan harga satu gulung lakban Rp5.000. Maka biaya 
overhead pabrik-biaya lakban untuk semua satu bungkus roti yaitu (Rp5.000:3.500=Rp1,4).

5. Biaya Isi Ulang Gas

Pada Bulan April Tahun 2017 Usaha Anandia Bakery memerlukan gas sebanyak 40 tabung isi $12 \mathrm{~kg}$. Harga satu tabung gas isi $12 \mathrm{~kg}$ adalah $\mathrm{Rp} 130.000$, jadi biaya isi ulang gas Usaha Anandia Bakery Bulan April Tahun 2017 sebesar Rp5.200.000. Maka biaya overhead pabrik-biaya isi ulang gas untuk semua jenis roti sama yaitu jumlah biaya isi ulang gas dibagi dengan total produksi selama Bulan April (Rp5.200.000:33.766=154).

Data mengenai biaya overhead pabrik per bungkus roti dapat dilihat pada tabel berikut:

Tabel 8

Biaya Overhead Pabrik pada Bulan April Tahun 2017 (dalam Rupiah)

\begin{tabular}{|c|c|c|c|c|c|c|c|c|c|c|c|}
\hline \multirow[b]{2}{*}{ No. } & \multirow[b]{2}{*}{ Jenis Biaya } & \multicolumn{10}{|c|}{ Jenis Roti } \\
\hline & & $\begin{array}{c}\text { Tawar } \\
\text { Panjang }\end{array}$ & $\begin{array}{c}\text { Tawar } \\
\text { Pendek }\end{array}$ & $\begin{array}{c}\text { Tawar } \\
\text { Pandan }\end{array}$ & $\begin{array}{l}\text { Tawar } \\
\text { Kupas }\end{array}$ & $\begin{array}{l}\text { Tawar } \\
\text { Mini }\end{array}$ & $\begin{array}{c}\text { Cokelat } \\
\text { Susu }\end{array}$ & $\begin{array}{c}\text { Manis } \\
\text { Susu }\end{array}$ & $\begin{array}{c}\text { Kelapa Isi } \\
5\end{array}$ & $\begin{array}{c}\text { Kelapa Isi } \\
10\end{array}$ & $\begin{array}{c}\text { Roti } \\
\text { Satuan }\end{array}$ \\
\hline 1 & Biaya Bahan Penolong & 135 & 108 & 429 & 429 & 90 & 676 & 273 & 434 & 867 & 77 \\
\hline 2 & Biaya Listrik Pabrik & 4,15 & 4,15 & 4,15 & 4,15 & 4,15 & 4,15 & 4,15 & 4,15 & 4,15 & 4,15 \\
\hline 3 & Biaya Pembungkus & 46 & 46 & 46 & 46 & 46 & 46 & 46 & 61 & 61 & 46 \\
\hline 4 & Biaya Lakban & 1,4 & 1,4 & 1,4 & 1,4 & 1,4 & 1,4 & 1,4 & 1,4 & 1,4 & 1,4 \\
\hline 5 & Biaya Isi Ulang Gas & 154 & 154 & 154 & 154 & 154 & 154 & 154 & 154 & 154 & 154 \\
\hline & Jumlah & 340,75 & 313,71 & 634,21 & 634,21 & 295,68 & 881,75 & 478,97 & 654,18 & $1.087,81$ & 282,81 \\
\hline
\end{tabular}

\section{Menghitung Biaya Variabel Setiap Daerah Pemasaran}

Tabel dibawah ini menampilkan biaya produksi variabel yang dikeluarkan Usaha Anandia Bakery untuk masing-masing daerah pemasaran Bulan April Tahun 2017.

Tabel 9

Rekapitulasi Biaya Produksi Variabel setiap Daerah Pemasaran pada Bulan April Tahun 2017 (dalam Rupiah)

\begin{tabular}{|l|l|r|r|r|}
\hline No. & \multicolumn{1}{|c|}{$\begin{array}{c}\text { Daerah } \\
\text { Pemasaran }\end{array}$} & \multicolumn{1}{|c|}{ BBB } & \multicolumn{1}{c|}{$\begin{array}{c}\text { BOP } \\
\text { Variabel }\end{array}$} & $\begin{array}{c}\text { Total Biaya } \\
\text { Produksi }\end{array}$ \\
\hline 1. & Kerinci & 23.779 .592 & 3.908 .920 & 27.688 .512 \\
\hline 2. & Panyabungan & 6.836 .652 & 1.095 .773 & 7.932 .425 \\
\hline 3. & Padang Panjang & 1.339 .665 & 237.438 & 1.577 .102 \\
\hline 4. & Kayu Aro & 5.279 .462 & 969.323 & 6.248 .785 \\
\hline 5. & Bangko & 17.272 .279 & 2.964 .282 & 20.236 .562 \\
\hline 6. & Padang & 6.398 .122 & 2.067 .301 & 8.465 .423 \\
\hline 7. & Pasaman & 12.070 .993 & 2.165 .326 & 14.236 .319 \\
\hline & Jumlah Biaya & $\mathbf{7 2 . 9 7 6 . 7 6 4}$ & $\mathbf{1 3 . 4 0 8 . 3 6 3}$ & $\mathbf{8 6 . 3 8 5 . 1 2 8}$ \\
\hline
\end{tabular}

Pembebanan biaya vaeriabel non produksi Usaha Anandia Bakery pada Bulan April Tahun 2017 adalah sebagai berikut:

1. Biaya telepon penjualan

Biaya telepon penjualan digunakan untuk mengkonfirmasi penjualan kepada setiap toko pada setiap daerah pemamasaran. Biasanya konfirmasi penjulan ini hanya pada toko yang tidak mencantumkan cap/stempel pada faktur penjualannya. Biaya telepon penjualan akan dibebankan kepada pelanggan sesuai dengan banyaknya toko yang tidak membubuhkan cap/stempel per daerah penjulan dikalikan dengan 
periode penjualan setiap bulannya. Berikut rincian frekuensi pengiriman dan jumlah pelanggan per daerah pemasaran:

Tabel 10

Konfirmasi Penjualan Bulan April Tahun 2017

\begin{tabular}{|l|l|c|c|}
\hline No. & \multicolumn{1}{|c|}{$\begin{array}{c}\text { Daerah } \\
\text { Pemasaran }\end{array}$} & $\begin{array}{c}\text { Frekuensi } \\
\text { Pengiriman }\end{array}$ & $\begin{array}{c}\text { Jumlah } \\
\text { Pelanggan }\end{array}$ \\
\hline 1. & Kerinci & 5 & 2 \\
\hline 2. & Penyambungan & 3 & 3 \\
\hline 3. & Padang Panjang & 2 & 5 \\
\hline 4. & Kayu Aro & 4 & 4 \\
\hline 5. & Bangko & 5 & 7 \\
\hline 6. & Padang & 7 & 3 \\
\hline 7. & Pasaman & 4 & 0 \\
\hline
\end{tabular}

Untuk satu kali melakukan konfirmasi kepada toko pada daerah pemasaran akan memakan waktu kurang lebih selama 2 menit melalui handpone dengan kartu perdana telkomsel. Oleh karena itu tarif nelpon per menit adalah Rp1.000. Jadi setiap melakukan konfirmasi ke pelanggan Ibu Susanti akan dikenai biaya nelpon sebesar Rp2.000 per pelanggan. Contoh perhitungan biaya konfirmasi penjualan untuk daerah Padang adalah, $7 * 3 *$ Rp2.000 = Rp42.000.

2. Biaya Pengiriman Produk

Biaya pengiriman produk dikeluarkan untuk aktivitas pengiriman produk ke tangan pelanggan. Usaha Anandia Bakery memberikan komisi untuk satu kali pengiriman ke daerah pemasaran sebanyak $12 \%$ dari total penjualan kepada sales. Contohnya, komisi yang akan diperoleh sales untuk pengiriman barang ke pelanggan di Padang yaitu: Rp19.527.800*12\% = Rp2.343.336. Karena persentase komisi yang diberikan kepada sales lumayan besar, maka semua biaya yang timbul diperjalanan ditanggung oleh sales itu sendiri, termasuk biaya bahan bakar minyak, tapi tidak untuk biaya servis mobil karena biaya tersebut akan ditanggung oleh Anandia Bakery.

3. Biaya Pencairan Giro

Ada beberapa pelanggan Usaha Anandia Bakery dalam pembanyaran utangnya melalui giro, diantaranya daerah Kerinci dan daerah Penyambungan. Pada daerah Kerinci ada 2 pelanggan yang melakukan pembayaran dengan giro, sedangkan pada daerah Penyambungan ada 4 pelanggan. Biaya yang dikeluarkan dalam satu kali pencairan giro adalah Rp10.000. Biaya pencairan giro ini merupakan biaya yang dikeluarkan untuk biaya transportasi dari rumah Ibu Susanti ke bank. Pada daerah Kerinci terjadi 5 kali periode penjualan maka, biaya pencairan giro adalah $5^{*} 2^{*} \operatorname{Rp} 10.000=$ Rp100.000. Sedangkan pada daerah Penyambungan terjadi 3 kali periode penjualan maka, biaya pencairan giro sebanyak $3^{*} 4^{*} \mathrm{Rp} 10.000=\mathrm{Rp} 120.000$.

Berikut adalah penjabaran biaya variabel non produksi ke setiap daerah pemasaran: 
Tabel 11

\begin{tabular}{|l|l|r|r|r|r|}
\hline \multicolumn{6}{|c|}{ Pembebanan Biaya Variabel Non Produksi ke Daerah Pemasaran } \\
\hline \multicolumn{5}{|c|}{ pada Bulan April Tahun 2017 (dalam Rupiah) } \\
\hline \multirow{2}{*}{ No. } & $\begin{array}{c}\text { Daerah } \\
\text { Pe masaran }\end{array}$ & $\begin{array}{c}\text { Telepon } \\
\text { Penjualan }\end{array}$ & $\begin{array}{c}\text { Pengiriman } \\
\text { produk }\end{array}$ & $\begin{array}{c}\text { Pencairan } \\
\text { Giro }\end{array}$ & $\begin{array}{c}\text { Variabel Non } \\
\text { Produksi }\end{array}$ \\
\cline { 3 - 6 } & Kerinci & 20.000 & 7.970 .712 & 100.000 & 8.090 .712 \\
\hline 1. & 18.000 & 2.316 .816 & 120.000 & 2.454 .816 \\
\hline 2. & Panyabungan & 20.000 & 450.504 & - & 470.504 \\
\hline 3. & Padang Panjang & 32.000 & 1.831 .236 & - & 1.863 .236 \\
\hline 4. & Kayu Aro & 70.000 & 5.769 .228 & - & 5.839 .228 \\
\hline 5. & Bangko & 42.000 & 2.343 .336 & - & 2.385 .336 \\
\hline 6. & Padang & - & 4.025 .628 & - & 4.025 .628 \\
\hline 7. & Pasaman & $\mathbf{2 0 2 . 0 0 0}$ & $\mathbf{2 4 . 7 0 7 . 4 6 0}$ & $\mathbf{2 2 0 . 0 0 0}$ & $\mathbf{2 5 . 1 2 9 . 4 6 0}$ \\
\hline
\end{tabular}

\section{Mengklasifikasikan Biaya Tetap}

Biaya tetap Bulan April Tahun 2017 terdiri dari biaya tenaga kerja tidak langsung, biaya listrik pabrik, biaya pelumas, biaya perlengkapan pabrik, biaya sewa tanah, biaya penyusutan bangunan pabrik, biaya peralatan pabrik, biaya penyusutan mesin produksi, biaya perlengkapan kantor, biaya gaji karyawan kantor (pemilik), biaya gaji sopir dan tenaga angkut, biaya penyusutan aktiva tetap (mobil), dan biaya pemeliharaan aktiva tetap (mobil). Biaya tetap yang dikeluarkan oleh Usaha Anandia Bakery selama Bulan April Tahun 2017 seluruhnya merupakan biaya tetap bersama (common fixed costs) karena biaya ini dikeluarkan untuk kegiatan operasional dan memberikan pelayanan untuk semua pelanggan.

\section{Menyusun Laporan Segmen Daerah Pemasaran}

Sumbangan laba setiap daerah pemasaran dapat tercermin dari margin segmen yang dihasilkan oleh setiap daerah pemasaran. Selanjutnya, margin segmen dapat disajikan dalam bentuk rasio yang disebut rasio margin segmen. Rasio margin segmen mencerminkan profitabilitas setiap daerah pemasaran yang merupakan kemampuan setiap daerah pemasaran dalam memberikan keuntungan bagi perusahaan. Semakin besar rasionya, maka kinerja dalam menghasilkan laba pada daerah pemasaran tersebut semakin baik. Laporan segemen daerah pemasaran ini dapat diketahui dengan pengurangkan total penjualan dengan semua biaya variabel dan biaya tetap langsung per daerah pemasaran. Tabel dibawah ini akan menyajikan laporan segmen daerah pemasaran Usaha Anandia Bakery Bulan April Tahun 2017: 
Tabel 12

Customer Profitability Statement "ANANDIYA BAKERY"

Bulan April Tahun 2017 (dalam Rupiah)

\begin{tabular}{|c|c|c|c|c|c|c|c|c|}
\hline \multirow[b]{2}{*}{ Keterangan } & \multicolumn{7}{|c|}{ Daerah Pemasaran } & \multirow[b]{2}{*}{ Total } \\
\hline & Kerinci & Panyabungan & $\begin{array}{l}\text { Padang } \\
\text { Panjang } \\
\end{array}$ & Kayu Aro & Bangko & Padang & Pasaman & \\
\hline Penjualan & 66.422 .600 & 19.306 .800 & 3.754 .200 & 15.260 .300 & 48.076 .900 & 19.527 .800 & 33.546 .900 & 205.895 .500 \\
\hline \multicolumn{9}{|l|}{ Biaya Variabel } \\
\hline Harga Pokok Penjualan Variabel & $(27.688 .512)$ & $(7.932 .425)$ & $(1.577 .102)$ & $(6.248 .785)$ & $(20.236 .562)$ & $\begin{array}{l}(8.465 .423) \\
\end{array}$ & $(14.236 .319)$ & $(86.385 .128)$ \\
\hline Biaya Administrasi variabel (Telepon) & $(20.000)$ & $(18.000)$ & $(20.000)$ & $(32.000)$ & $(70.000)$ & $(42.000)$ & & $(202.000)$ \\
\hline Biaya Administrasi variabel (Pencairan Giro) & $(100.000)$ & $(120.000)$ & - & - & - & & & $(220.000)$ \\
\hline Biaya Pemasaran Variabel (Pengiriman Produk) & $(7.970 .712)$ & $(2.316 .816)$ & $(450.504)$ & $(1.831 .236)$ & $(5.769 .228)$ & $(2.343 .336)$ & $(4.025 .628)$ & $(24.707 .460)$ \\
\hline Margin kontribusi & 30.643 .376 & 8.919 .559 & 1.706 .594 & $\begin{array}{ll}7.148 .279 \\
\end{array}$ & 22.001 .110 & 8.677 .041 & 15.284 .953 & 94.380 .912 \\
\hline \multicolumn{9}{|l|}{ Biaya Tetap Langsung ke Pelanggan } \\
\hline Margin Segmen & 30.643 .376 & 8.919 .559 & 1.706 .594 & 7.148.279 & 22.001 .110 & 8.677 .041 & 15.284 .953 & 94.380 .912 \\
\hline \multicolumn{9}{|l|}{ Biaya Tetap Produksi } \\
\hline Biaya Tenaga Kerja Tidak Langsung & & & & & & & & $(20.700 .000)$ \\
\hline Biaya Listrik Pabrik & & & & & & & & $(622.000)$ \\
\hline Biaya Pelumas & & & & & & & & $(20.000)$ \\
\hline Biaya Perlengkapan Pabrik & & & & & & & & $(24.000)$ \\
\hline Biaya Sewa Tanah & & & & & & & & $(500.000)$ \\
\hline Biaya Penyusutan Bangunan Pabrik & & & & & & & & $(416.667)$ \\
\hline Biaya Penyusutan Pelaratan Pabrik & & & & & & & & $(305.208)$ \\
\hline Biaya Penyusutan Mesin Pabrik & & & & & & & & $(1.609 .375)$ \\
\hline \multicolumn{9}{|l|}{ Biaya Tetap Non Produksi } \\
\hline $\begin{array}{l}\text { Biaya Perlengkapan } \\
\end{array}$ & & & & & & & & $(20.000)$ \\
\hline Biaya Gaji Sopir dan Tenaga Angkut & & & & & & & & $(2.700 .000)$ \\
\hline Biaya Penyusutan Kendaraan & & & & & & & & $(3.333 .333)$ \\
\hline Biaya Pemeliharaan Kendaraan & & & & & & & & $(950.000)$ \\
\hline Rugi Atas Produk Rusak & & & & & & & & $\begin{array}{l}(15.735 .164) \\
\end{array}$ \\
\hline LABA & & & & & & & & 47.445 .165 \\
\hline
\end{tabular}

Berdasarkan laporan segmen diatas, dapat diketahui tingkat profitabilitas yang diberikan oleh masing-masing daerah pemasaran terhadap perusahaan. Besarnya tingkat profitabilitas dapat dilihat dari rasio margin segmen. Rasio margin segmen dapat diketahui dengan membagi penjualan dan margin segmen. Berikut adalah rasio margin segmen masing-masing daerah pemasaran.

Tabel 15

\begin{tabular}{|c|c|c|c|c|}
\hline \multicolumn{5}{|c|}{ Rasio Margin Segmen Daerah Pemasaran Bulan April Tahun 2017} \\
\hline No. & $\begin{array}{c}\text { Daerah } \\
\text { Pemasaran }\end{array}$ & $\begin{array}{c}\text { Penjualan } \\
\text { (Rp) }\end{array}$ & $\begin{array}{c}\text { Margin } \\
\text { Segmen (Rp) }\end{array}$ & $\begin{array}{c}\text { Rasio Margin } \\
\text { Segmen }\end{array}$ \\
\hline 1 & Kerinci & 66.422 .600 & 30.643 .376 & $46,13 \%$ \\
\hline 2 & Panyabungan & 19.306 .800 & 8.919 .559 & $46,20 \%$ \\
\hline 3 & Padang Panjang & 3.754 .200 & 1.706 .594 & $45,46 \%$ \\
\hline 4 & Kayu Aro & 15.260 .300 & 7.148 .279 & $46,84 \%$ \\
\hline 5 & Bangko & 48.076 .900 & 22.001 .110 & $45,76 \%$ \\
\hline 6 & Padang & 19.527 .800 & 8.677 .041 & $44,43 \%$ \\
\hline 7 & Pasaman & 33.546 .900 & 15.284 .953 & $45,56 \%$ \\
\hline
\end{tabular}

Semua pelanggan yang dimiliki Anandia Bakery pada Bulan April Tahun 2017 merupakan pelanggan yang menguntungkan, yang dibuktikan dengan rasio margin dari masing-masing pelanggan tinggi dan tidak jauh berbeda antara satu dengan lainnya.

Berdasarkan rasio margin segemen per daerah pemasaran, Daerah Kayu Aro adalah daerah pemasaran yang paling besar memberikan persentase laba. Hal ini dikarenakan harga jual roti pada Daerah Kayu Aro lebih tinggi dari pada daerah lainnya yang berada di dalam provinsi, tapi harga jual tersebut sama dengan harga 
jual roti pada daerah pemasaran yang berada diluar Provinsi Sumatera Barat. Namun untuk biaya administrasi, Daerah Kayu Aro lebih rendah pada Daerah Kerinci, Bangko, dan Panyabungan. Contohnya saja pada Daerah Kerinci dan Panyabungan Anandia Bakery harus mengeluarkan biaya tranfortasi untuk pencairan giro pada bank, sedangkan untuk Daerah Kayu Aro tidak ada. Selain itu pada Daerah Kayu Aro pelanggan yang penjualannya harus dikonfirmasi ulang oleh Anandia Bakery lebih sedikit dari Daerah Bangko, masing-masing yaitu 4 dan 7 pelanggan.

\section{KESIMPULAN DAN SARAN}

\section{Kesimpulan}

Berdasarkan laporan segmen (Segmented reporting) Usaha Anandia Bakery pada Bulan April Tahun 2017, maka dapat disimpulkan sebagai berikut:

1. Usaha Anandia Bakery merupakan usaha manufaktur yang bergerak dalam pembuatan berbagai macam roti.

2. Usaha Anandia Bakery memiliki 7 daerah pemasaran aktif yaitu, Daerah Kerinci, Panyabungan, Padang Panjang, Kayu Aro, Bangko, Padang, dan Pasaman.

3. Berdasarkan laporan segmen (Segmented reporting) Usaha Anandia Bakery pada Bulan April Tahun 2017, semua pelanggan yang dimiliki merupakan pelanggan yang menguntungkan.

4. Profitabilitas setiap daerah pemasaran dapat tercermin dari rasio margin segmen.

5. Daerah Kayu Aro merupakan daerah yang memberikan kontribusi laba tertinggi.

\section{Saran}

Dari kesimpulan diatas, maka Penulis menyarankan kepada pembaca khusunya kepada Anandia Bakery supaya:

1. Memiliki pelanggan yang memenuhi kategori Winners dan menguntungkan Anandia Bakery sebaiknya mempertahankan usaha penjualan dan aktivitas pelayanan yang telah diberikan.

2. Anandia Bakery sebaiknya melakukan pelaporan segmen dengan pendekatan variabel costing. Pelaporan segmen dengan pendekatan variabel costing dapat memberikan informasi yang akurat tentang profitabilitas setiap daerah pemasaran.

3. Informasi profitabilitas setiap daerah pemasaran dapat digunakan sebagai dasar dalam melakukan perencanaan program atau strategi yang akan dilakukan perusahaan untuk mempengaruhi kebiasaan pelanggan dalam melakukan pembelian, sehingga dapat meningkatkan laba perusahaan secara keseluruhan.

\section{REFERENSI}

Blocher, E.J., Stout, D.E., dan Cokins, G., (2012). Menajemen biaya penekanan strategis (edisi ke-5). Jakarta: Salemba Empat.

Carter, W.K., (2009). Akuntansi biaya (edisi ke-4). Jakarta: Salemba Empat.

Garrison, R.H., Noreen, E.W., dan Brewer, P.C., (2006). Akuntansi manajerial (edisi ke11). Jakarta: Salemba Empat. 
Hansen, D.R., dan Mowen, M.M., (2009). Akuntansi manajerial (edisi-8). Jakarta: Salaemba Empat.

Riwayadi, (2016). Akuntansi Biaya (edisi-2). Jakarta:Salemba Empat.

Rudianto, (2006). Akuntansi menajemen. Jakarta: PT Gransindo.

Samryn, L.M., (2013). Akuntansi manajemen (edisi revisi). Jakarta: Kencana.

Siregar, B., Suripto, B., Hapsoro, D., Lo, E.W., Herowati, E., Kusumasari, L., dan Nurofik, (2013). Akuntansi biaya (edisi-2).Jakarta: Salemba Empat. 